\title{
Erratum: Should development of Alzheimer's disease-specific intravenous immunoglobulin be considered?
}

\author{
David A Loeffler
}

\section{Erratum}

After publication of our article [1], it came to our attention that we had erroneously stated that the IVIG product NewGam was produced by Sutter Health. However, Octapharma is the manufacturer of NewGamTM and Sutter Health is the sponsor of the clinical trial. Therefore the following sentence on page 2 of the original manuscript [1] is incorrect: "The effects of Sutter Health's IVIG NewGamTM are also being examined in individuals with mild cognitive impairment (MCI) [33], thought to be the transitional state between the cognitive changes of normal aging and very early dementia [34]." This sentence should read as follows: "The effects of Octapharma's IVIG NewGamTM are also being examined in individuals with mild cognitive impairment (MCI) [33], thought to be the transitional state between the cognitive changes of normal aging and very early dementia [34]."

\section{Competing interests}

The author declares that he has no competing interests.

Received: 4 March 2015 Accepted: 4 March 2015

Published online: 09 April 2015

\section{Reference}

1. Loeffler DA. Should development of Alzheimer's disease-specific intravenous immunoglobulin be considered? J Neuroinflammation. 2014;11:198.

Submit your next manuscript to BioMed Central and take full advantage of:

- Convenient online submission

- Thorough peer review

- No space constraints or color figure charges

- Immediate publication on acceptance

- Inclusion in PubMed, CAS, Scopus and Google Scholar

- Research which is freely available for redistribution 